\title{
Transient sediment load on blades of Arctic Saccharina latissima can mitigate UV radiation effect on photosynthesis
}

\author{
Michael Y. Roleda $\cdot$ Dirk Dethleff $\cdot$ Christian Wiencke
}

Received: 11 October 2007 / Revised: 17 January 2008 / Accepted: 27 February 2008 / Published online: 11 March 2008

(C) Springer-Verlag 2008

\begin{abstract}
We studied the short-term impact of sediment load on the photosynthetic performance of Saccharina latissima sporophytes exposed to ultraviolet radiation (UVR). The algae were collected from different sedimentinfluenced environments in Svalbard in August 2007. Initial optimum quantum yield $\left(F_{\mathrm{v}} / F_{\mathrm{m}}\right)$ of sediment-covered sporophytes was significantly higher compared to sediment-free sporophytes. Experimental sediment coating on blade discs had a photoprotective function by screening out $92 \%$ of the weighted UV-B ( $\left.\mathrm{UV}_{\text {ery }}\right)$ treatment. No UVRinduced photoinhibition was observed in sediment-coated blade discs while sediment removal caused a reduction in $F_{\mathrm{v}} / F_{\mathrm{m}}$ not only after 12 -h UVR exposure but also after 6-h recovery in low white light compared to the initial value. Thus, sediment coating has a short-term functional significance in mitigating the negative effect of UVR on photosynthesis of an important kelp species and set a baseline for further studies.
\end{abstract}

Keywords Ablation-derived siltation $\cdot$ Arctic fjord system $\cdot$ Climate change $\cdot F_{\mathrm{v}} / F_{\mathrm{m}} \cdot$ Optimum quantum yield

Electronic supplementary material The online version of this article (doi:10.1007/s00300-008-0434-z) contains supplementary material, which is available to authorized users.

M. Y. Roleda $(\varangle) \cdot$ D. Dethleff

Institute for Polar Ecology, University of Kiel,

Wischhofstrasse 1-3, Building 12, 24148 Kiel, Germany

e-mail: mroleda@ipoe.uni-kiel.de

C. Wiencke

Section Seaweed Biology,

Alfred Wegener Institute for Polar and Marine Research,

Am Handelshafen 12, 27570 Bremerhaven, Germany

\section{Introduction}

Macroalgae are major primary producers on rocky shores and continental shelves. Solar UV-B radiation constitutes a significant stressor resulting in a number of biological effects on the molecular, cellular, individual and community levels (Bischof et al. 2006; Roleda et al. 2007). Light attenuation of the water column is controlled by scattering and absorption of the respective seawater body. In particular, the short UV-B wavelengths are strongly attenuated in coastal waters with high concentration of dissolved organic matter (Tedetti and Sempéré 2006). Macroalgae can, however, be exposed to intense ambient solar radiation during extreme low-water spring tides (S1). Aside from light stress, eulittoral and upper sublittoral macroalgae can also be exposed to other abiotic factors such as high or low temperature, osmotic and desiccation stress during emersion.

During Arctic summer, turbid freshwater from melting snow layers and glaciers, as well as from precipitation is discharged into Kongsfjorden (Hanelt et al. 2001; Svendsen et al. 2002). The Bayelva River drains an annual average of $6.95 \times 10^{6} \mathrm{~m}^{3}$ melt water transporting 11,000 tons of sediment to Kolhamna Bay (Hagen and Lefauconnier 1995; Bogen and Bonsnes 2003). With increasing glacier-derived and terrestrial melt water volume exported into the fjord (Zajaczowski et al. 2004); the above-mentioned figures represent conservative estimates on the present status of climate change-induced sediment flux into an Arctic coastal marine ecosystem. The sediment transported into the fjord leads to visible sediment coating on the blades of macroalgae (S1).

Long term sediment burial significantly reduces biomass on some macroalgal species but the thalli remain viable. Crustose coralline and filamentous turf algae, as well as Sargassum C. Agardh species were found to be more 
resilient to sedimentation compared to Codium Stackhouse, Ulva Linnaeus and Gracilariopsis E. Y. Dawson (Airoldi 2003 and references therein). Survival of brown macroalgal spores and zygotes can, however, be negatively affected under the influence of sediment burial (Devinny and Volse 1978; Chapman and Fletcher 2002). More studies in this field are urgently needed.

High Arctic marine ecosystems are subjected to multistress factors such as increasing UV-B radiation due to a decrease of stratospheric ozone and increasing particulate matter fluxes due to global warming-induced ablation and increase in local precipitation (Førland et al. 2002; Zajaczowski et al. 2004). The seasonal sediment input and the particle load on thallus of macroalgal can, however, be resuspended and flushed out from the system by the local hydrodynamic processes. Sediment cover on blades of macroalgae can therefore be transient, short-term or seasonal. Concurrent to sedimentation stress during polar summer, macroalgal assemblage could be exposed to high solar radiation during extreme low-water at spring tides.

To our knowledge no studies have been conducted on the short-term impact of sediment load on the photosynthetic performance of macroalgae exposed to ultraviolet radiation (UVR). Moreover, the functional significance of an environmental disturbance in mitigating another environmental stress factor has never been addressed. This study was designed to determine the photosynthetic performance of Saccharina latissima (Linnaeus) C.E. Lane, C. Mayes, Druehl and G.W. Saunders collected from sites with different sediment load impacts. Experimental sediment coating was performed in the laboratory to assess whether transient sediment load has a negative impact on the photosynthetic capacity or short-term photoprotective function against UVR.

\section{Material and methods}

\section{Algal material}

Saccharina latissima sporophytes originating from an extremely sediment-influenced site in Kolhamna Bay $\left(78^{\circ} 56.195^{\prime} \mathrm{N}, 11^{\circ} 52.918^{\prime} \mathrm{E}\right)$ close to the mouth of Bayelva River (Fig. 1) and in a low impact sediment-influenced site in Brandal $\left(78^{\circ} 56.87^{\prime} \mathrm{N}, 11^{\circ} 51.64^{\prime} \mathrm{E}\right)$ were collected by SCUBA diving at 6-m depths in August 2007. Sporophytes collected from high sediment load environment were packed with occurring sediment cover. The samples were kept dark and cool during transport to the laboratory. Five sporophytes (size class of approximately $15-20 \mathrm{~cm}$ width and $1 \mathrm{~m}$ length) from both sites were chosen for the experiment. From each sporophyte, 8 discs $(3 \mathrm{~cm}$ diameter) were punched out of the middle of the blade equidistantly from

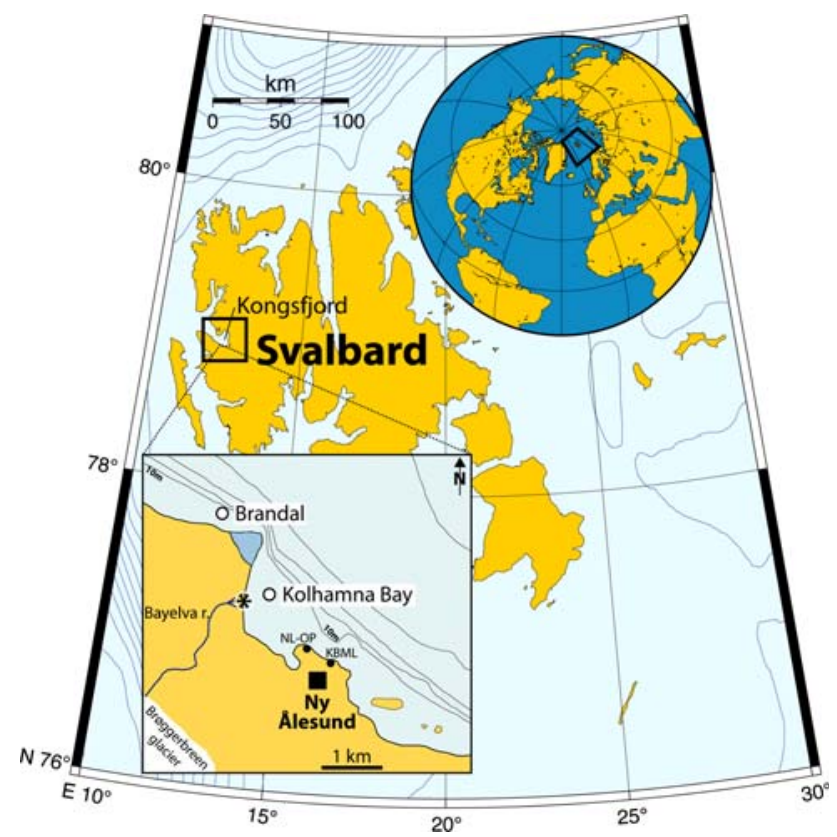

Fig. 1 Sampling stations for Saccharina latissima (open circles) in Kolhamna Bay and at Brandal and sediment collection site at the mouth of the Bayelva River (asterisk) in Kongsfjorden located at western Svalbard, correspondingly enlarged from broader geographic scope. KBML is Kings Bay Marine Laboratory and NL-OP is the Old Pier fronting Nansen Laboratory. Stations are in reference to an Electronic supplementary material Fig. S1

the base to the tip. This accounted for a total of 40 experimental units for each group. Each disc was put into individual Petri dish $(53 \mathrm{~mm} \times 12 \mathrm{~mm})$ with ambient fjord seawater $($ salinity $=33)$.

Sediment material

Sediment material was collected from the surface deposits in Bayelva river delta (Fig. 1). The same fine-grained sediment material is periodically discharged into the adjacent Kolhamna Bay observed covering the blades of the macroalgal assemblage in this vicinity (Dethleff et al. 2006; unpublished data). The sediment was resuspended in ambient fjord water and an equal amount of the suspension (approximately $5 \mathrm{ml}$ ) was injected into the Petri dishes using a $100 \mathrm{ml}$ syringe. Sediment was allowed to settle on the surface of the algae covering about $90 \%$ of the discs (S2) before exposure to experimental treatment.

\section{Irradiation treatment}

White fluorescent tubes (Osram, L65 Watt/25S, Munich, Germany) and UVA-340 fluorescent tubes (Q-Panel, Cleveland, OH, USA) were used to provide photosynthetically active radiation (PAR, $400-700 \mathrm{~nm}$ ) and ultraviolet radiation (UVR, 280-400 nm), respectively. PAR, measured 


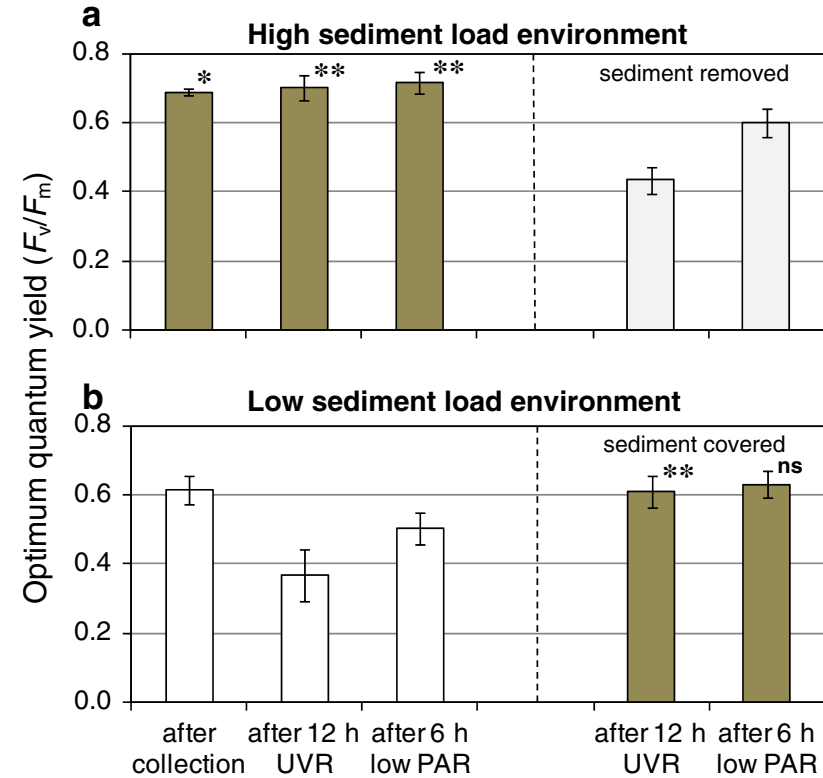

Fig. 2 Mean optimum quantum yield of Saccharina latissima blade discs derived from sporophytes originating from high (a) versus low (b) sediment load environment at Kolhamna Bay and Brandal, respectively. Sediment-coated (shaded bars) and sediment-free discs (open bars) were exposed to ultraviolet radiation and allowed to recover at low white light. The effect of reversed sediment-coating is shown on the right. Vertical bars are standard deviation $(n=5)$. Significant difference between experimental groups (a vs. b) was tested using oneway ANOVA. Asterisks suggest $F_{\mathrm{v}} / F_{\mathrm{m}}$ of sediment-coated discs is significantly higher than sediment-free discs at $P<0.01$, and $* * P<0.001 ; n s$ not significantly different $(P=0.263)$

using a cosine quantum sensor attached to a LI-COR data logger (LI-1400, LI-COR Biosciences, Lincoln, Nebraska, USA), was $22 \mu \mathrm{mol}$ photon $\mathrm{m}^{-2} \mathrm{~s}^{-1}\left(\sim 4.73 \mathrm{~W} \mathrm{~m}^{-2}\right)$. Ultraviolet radiation was measured using Solar Light PMA 2100 radiometer equipped with a UV-A sensor PMA 2110 and a UV-B Sensor PMA 2106 (Solar light, Philadelphia, USA). Adjusted ultraviolet radiation was $4.34 \mathrm{~W} \mathrm{~m}^{-2} \mathrm{UV}-\mathrm{A}$ and $0.40 \mathrm{~W} \mathrm{~m}^{-2}$ UV-B.

\section{Biological effective UV dose and radiation attenuation}

The amount of UV-B (erythema weighted, $\mathrm{UV}_{\text {ery }}$; El Naggar et al. 1995) emitted by the Q-Panel lamps on air, and transmitted through the water and sediment cover was measured using an ELUV 14 data logger. For underwater measurements, the data logger enclosed in water-tight casing was submerged into seawater-containing basin. The same amount of sediment load comparable to those covering the algal disc was then injected into the basin covering the surface of the UV-transparent glass-covered sensor of the encased data logger. The data logger was submerged with the sensor $12 \mathrm{~mm}$ below the air-water interface comparable to the water level inside the Petri dishes with algal discs.
Percent radiation attenuation was computed as the difference in weighted UV-B fluence between measurements on air-water interface, underwater and under sediment coating. The sensitivity of the data logger was calibrated to the standard CIE-87 erythemal response (McKinlay and Diffey 1987).

\section{PAM-fluorometry}

Photosynthetic activity of blade discs was measured as optimum quantum yield of photosystem II $\left(F_{\mathrm{v}} / F_{\mathrm{m}}=\right.$ $\left.\left(F_{\mathrm{m}}-F_{0}\right) / F_{\mathrm{m}}\right)$ using a PAM-2100 chlorophyll fluorometer (Walz, Effeltrich, Germany). Samples were kept in darkness for $3 \mathrm{~min}$ and $F_{\mathrm{v}} / F_{\mathrm{m}}$ was measured according to Hanelt (1998). Sediment-covered discs were freed of particles before dark incubations.

Experimental design

Initial $F_{\mathrm{v}} / F_{\mathrm{m}}$ of dark adapted blade discs originating from both high and low sediment load environments was measured immediately (circa $2 \mathrm{~h}$ ) after algal collection. After measurement, blade discs originating from the high sediment load environment were re-coated with sediment and together with the uncoated discs originating from low sediment load environment were exposed to the above described radiation conditions. After 12-h exposure to the whole radiation spectrum and 6-h recovery in low PAR $\left(10 \mu \mathrm{mol}\right.$ photons $\left.\mathrm{m}^{-2} \mathrm{~s}^{-1}\right)$, photosynthetic efficiency was measured again. After this treatment, the formerly sediment-free discs originating from low sediment environment were coated with sediment while the previously sedimentcovered discs originating from high sediment environment were freed of particles. The discs were again exposed to $12 \mathrm{~h}$ of the whole light spectrum and 6-h recovery period and $F_{\mathrm{v}} / F_{\mathrm{m}}$ was measured correspondingly.

Sediment analysis

After both experimental UV exposures, sediment particles from individual disc were separately collected, individually filtered through a pre-weighed $0.45-\mu \mathrm{m}$ Millipore filters, oven-dried at $63^{\circ} \mathrm{C}$ and weighed. The mean sediment cover on the disc's surface area was calculated in $\mathrm{mg} \mathrm{cm}^{-2}$. The amount of sediment settled on the bottom of the Petri dishes were also collected to calculate the total sediment injected into each individual dish. Grain-size distribution (sand: $>63 \mu \mathrm{m}$; silt: $2-63 \mu \mathrm{m}$; clay: $<2 \mu \mathrm{m}$ ) and bulk particle composition (e.g. rock materials, minerals and biogenic particles) of the samples were qualified and quantified using a binocular $(50 \times$, Zeiss $)$ and by smear slide using a microscope (200-300×, Leitz Aristoplan) equipped with a camera (Sony DXC-930P). 
Statistical analysis

The mean $F_{\mathrm{v}} / F_{\mathrm{m}}$ for each sporophyte (eight pseudoreplicates) was computed. Data were tested for homogeneity of variance (Levene Statistics). The significant difference in photosynthetic efficiency between the two experimental groups $(n=5)$ during UVR exposure and recovery was tested using one-way analysis of variance (ANOVA, $P>0.05)$ with SPSS program (Chicago, IL, USA).

\section{Results}

The sediment suspension contained an average of $25.2 \mathrm{mg} \mathrm{DW} \mathrm{ml}^{-1}$ particles. Mean particle load on the disc area was $6.84 \pm 1.16 \mathrm{mg} \mathrm{cm}^{-2}$. The sediment consisted of $40-60 \%$ sand, $30-50 \%$ silt, and $10 \%$ clay. The silty and clayey fine sand was composed of 75-85\% quartz and feldspar grains, $3 \%$ rock fragments, $12 \%$ dark minerals, and $<1 \%$ mica and biogenic materials.

Weighted UV-B at the water surface was $26 \mathrm{~mW} \mathrm{~m}^{-2}$ $\mathrm{UV}_{\text {ery }}$. About $9 \%$ of which was attenuated through the $12 \mathrm{~mm}$ of seawater down to $24 \mathrm{~mW} \mathrm{~m}^{-2} \mathrm{UV}_{\text {ery }}$ reaching the blade discs. The sediment coating cut-off the UV-B radiation further by $92 \%$ and only $1.6 \mathrm{~mW} \mathrm{~m}^{-2} \mathrm{UV}_{\text {ery }}$, i.e. $6.2 \%$ of the UV-B at the water surface reached the blade discs.

Initial optimum quantum yield $\left(F_{\mathrm{v}} / F_{\mathrm{m}}\right)$ of sporophytes originating from high sediment load environment $(0.690 \pm 0.02)$ was significantly higher (one-way ANOVA, $P<0.01)$ compared to sporophytes originating from low sediment load environment $(0.616 \pm 0.07)$. Exposure to UVR in the laboratory did not significantly affect the photosynthetic capacity of sediment-coated discs (Fig. 2a) while $40 \%$ reduction in $F_{\mathrm{v}} / F_{\mathrm{m}}$ was observed in sediment-free discs (Fig. 2b). Partial photosynthetic recovery in UVRexposed discs (38\%) was observed after 6-h post-cultivation in low PAR. This was $18 \%$ lower compared to the initial $F_{\mathrm{v}} / F_{\mathrm{m}}$ of the sediment-free sporophytes.

Reverse sediment treatment showed that the previously sediment-coated discs and now UVR-exposed showed 39\% reduction in $F_{\mathrm{v}} / F_{\mathrm{m}}$ comparable to that of the discs from sediment-free sporophytes. Recovery of photosynthetic capacity after UVR exposure was comparable at $38 \% . F_{\mathrm{v}} / F_{\mathrm{m}}$ after UVR treatment and after $6 \mathrm{~h}$ recovery is significantly different. $F_{\mathrm{v}} / F_{\mathrm{m}}$ at the end of the experiment is however $13 \%$ lower compared to the initial value of the sediment covered thallus. Conversely, the previously UVR-exposed discs and now sediment-coated, $F_{\mathrm{v}} / F_{\mathrm{m}}$ increased by $17 \%$ during UVR exposure treatment to value comparable to the initial $F_{\mathrm{v}} / F_{\mathrm{m}}$. During the recovery phase, a further $3 \%$ increase in $F_{\mathrm{v}} / F_{\mathrm{m}}$ was observed. The statistical difference in photosynthetic efficiency between experimental groups was shown in Fig. 2.

\section{Discussion}

The principal result of this study is that a transient sediment load on the blade of Saccharina latissima has a photoprotective function against UVR. The short-term "positive" effect of sediment coating on the photosynthetic performance of an Arctic kelp species under the influence of high solar radiation during polar days is reported for the first time.

Aside from UVR effect, the decrease in optimum quantum yield can also be caused by high PAR. In this study, the decrease in $F_{\mathrm{v}} / F_{\mathrm{m}}$ was attributed to UVR because the PAR fluence used was low (maximum $30 \mu \mathrm{mol}$ photon $\mathrm{m}^{-2} \mathrm{~s}^{-1}$ ) and does not cause photoinhibition (Roleda et al. 2004). Repeated exposure of juvenile sporophytes to ultraviolet radiation in the laboratory did not only affect photosynthetic performance of kelps but also growth, pigments and DNA (Roleda et al. 2004, 2005, 2006). Morphological damage such as bleaching, tissue blisters, lesions and deformation, and thickening of the meristematic lamina has been reported in Laminaria ochroleuca Bachelot de la Pylaie exposed to UVR (Roleda et al. 2004). Whether such morphological damage can be abated in the presence of sediment remains to be studied.

In very clear water, biologically relevant UV-B radiation penetrates the water column down to about 5-8 $\mathrm{m}$ depths (Hanelt et al. 2001). A decrease in 1\% UV-B depth from 6.87 to $3.57 \mathrm{~m}$ was reported with melt water inflow and sediment resuspension (Wiencke et al. 2006). Daily average vertical particle flux across nine sampling stations in Kolhamna Bay was spatially variable at $2.94 \pm$ $3.17 \mathrm{mg} \mathrm{cm}^{-2}$ day $^{-1}$ while a cumulative mean sediment load of $36.16 \pm 12.92 \mathrm{mg} \mathrm{cm}^{-2}$ was observed deposited on kelp blade surfaces (Dethleff unpublished data). Relative to the flux, the sediment coating artificially introduced onto the algal discs represented 2-3 days particle deposition and only $20 \%$ of the naturally occurring load accumulated over a longer period of time. The long-term negative impact of sediment load, such as the onset of tissue decay due to the absence of light and by hypoxia, on macroalgal blades remains to be studied.

The experimental sediment load and UVR levels applied in the laboratory can occur jointly in situ. During spring tides in summer, macroalgae had been observed exposed to high solar radiation without or with sediment cover (S1). The seasonal and dynamic change in the underwater light climate in Kongsfjorden due to freshwater input and suspended sediment particles (Ito and Kudoh 1997; Hanelt et al. 2001) effectively attenuate UVR and may to some extent provide a short-term beneficial effect on upper sublittoral macroalgal species exposed to excessive solar radiation. Macroalgal assemblage inhabiting sedimentinfluenced environments may also be favorably related to 
other factors correlated with sediments, e.g. nutrient availability (Umar et al. 1998). Changes in salinity due to freshwater input can, however, impose other adverse physiological effect.

Over the past 10 years, a significant increase in temperature and local precipitation was reported in Spitsbergen. Continuous future warming in the Norwegian Arctic (Førland et al. 2002) will further increase particulate matter fluxes into Spitsbergen fjords (Zajaczowski et al. 2004). There is clearly a need for further studies on the impact of melt water-derived sedimentation on the biological performance of macroalgae.

Acknowledgments We thank the diving group of AWI for collecting experimental material. This study is supported by the AWI and performed at the International Arctic Environmental Research and Monitoring Facility at Ny Ålesund, Svalbard.

\section{References}

Airoldi L (2003) The effects of sedimentation on rocky coast assemblages. Oceanogr Mar Biol 41:161-236

Bischof K, Gomez I, Molis M, Hanelt D, Karsten U, Lüder U, Roleda MY, Zacher K, Wiencke C (2006) Ultraviolet radiation shapes seaweed communities. Rev Environ Sci Biotechnol 5:141-166

Bogen J, Bonsnes TE (2003) Erosion and sediment transport in high Arctic rivers, Svalbard. Polar Res 22:175-189

Chapman AS, Fletcher RL (2002) Differential effects of sediments on survival and growth of Fucus serratus embryos (Fucales, Phaeophyceae). J Phycol 38:894-903

Dethleff D, Bischof K, Wiencke C, Deloffre J, Brey L, Lafite R (2006) AWIPEV-INVEST 2005--Sedimentological investigations at the coastal interface in shallow Kolhamnlaguna, Kongsfjorden, Western Svalbard. Mitt Kieler Polarforschg 22:14-41

Devinny JS, Volse LA (1978) Effects of sediments on the development of Macrocystis pyrifera gametophytes. Mar Biol 48:343-348

El Naggar S, Gustat H, Magister H, Rochlitzer R (1995) An electronic personal UV-B-dosimeter. J Photochem Photobiol B Biol 31:8386

Førland EJ, Hanssen-Bauer I, Jónsson T, Kern-Hansen C, Nordli PØ, Tveito OE, Vaarby Laursen E (2002) Twentieth century variations in temperature and precipitation in the Nordic Arctic. Polar Rec 38:203-210
Hagen JO, Lefauconnier B (1995) Reconstructed runoff from the high Arctic Basin Bayelva based on mass-balance measurements. Nord Hydrol 26:285-296

Hanelt D (1988) Capability of dynamic photoinhibition in Arctic macroalgae is related to their depth distribution. Mar Biol 131:361369

Hanelt D, Tüg H, Bischof K, Gross C, Lippert H, Sawall T, Wiencke C (2001) Light regime in an Arctic fjord: a study related to stratospheric ozone depletion as a basis for determination of UV effects on algal growth. Mar Biol 138:649-658

Ito H, Kudoh S (1997) Characteristics of water in Kongsfjorden, Svalbard. Proc NIPR Symp Polar Meteorol Glaciol 11:211-232

McKinlay AF, Diffey BL (1987) A reference action spectrum for ultraviolet induced erythema in human skin, vol 6. CIE Research Note, CIE-Journal, pp 17-22

Roleda MY, Hanelt D, Kräbs G, Wiencke C (2004) Morphology, growth, photosynthesis and pigments in Laminaria ochroleuca (Laminariales, Phaeophyta) under ultraviolet radiation. Phycologia 43:603-613

Roleda MY, Hanelt D, Wiencke C (2005) Growth kinetics related to physiological parameters in young Sacchorhiza dermatodea and Alaria esculenta sporophytes exposed to UV radiation. Polar Biol 28:539-549

Roleda MY, Wiencke C, Hanelt D (2006) Thallus morphology and optical characteristics affect growth and DNA damage by UV radiation in juvenile Arctic Laminaria sporophytes. Planta 223:407-417

Roleda MY, Wiencke C, Hanelt D, Bischof K (2007) Sensitivity of the early life stages of macroalgae from the Northern Hemisphere to ultraviolet radiation. Photochem Photobiol 83:851-862

Svendsen H, Beszczynska-Møller A, Lefauconnier B, Tverberg V, Gerland S, Hagen JO, Ørbæk JB, Bischof K, Papucci C, Zajaczkowski M, Azzolini R, Bruland O, Wiencke C, Winther JG, Hodson A, Mumford P (2002) The physical environment of Kongsfjorden-Krossfjorden, an Arctic fjord system in Svalbard. Polar Res 21:133-166

Tedetti M, Sempéré R (2006) Penetration of ultraviolet radiation in the marine environment. A review. Photochem Photobiol 82:389-397

Umar MJ, McCook LJ, Price IR (1998) Effects of sediment deposition on the seaweed Sargassum on a fringing reef. Coral Reef 17:169177

Wiencke C, Roleda MY, Gruber A, Clayton MN, Bischof K (2006) Susceptibility of zoospores to UV radiation determines upper depth distribution limit of Arctic kelps: evidence through field experiments. J Ecol 94:455-463

Zajaczowski M, Szczucinski W, Bojanowski R (2004) Recent changes in sediment accumulation rates in Adventfjorden, Svalbard. Oceanologia 46:217-231 